\title{
Effects of Sex Hormone on the Dilatation of Urinary Tubule and Acidophil Body in NON Mice
}

\author{
Hitomi SAHATA, Syusaku SUZUKI*, Akio AGO**, Hiroharu \\ MIFUNE***, and Hiroshi SAKAMOTO**** \\ Shimane Insutitute of Helth Science, 223-7 Enya-cho, Izumo-shi, Shimane 693, "Insutitute of \\ Laboratory Animal Sciences, Faculty of Medicine, Kagoshima University, 8-35-1 \\ Sakuragaoka, Kagoshima-shi, Kagoshima 890, ${ }^{* *}$ Institute of Experimental \\ Animals Insernal Medicine, Shimane Medical University, 89-1 Enya-cho, \\ Izumo-shi, Shimane 693, ${ }^{* *}$ Institute of Animal Experiment, \\ Kurume University School of Medicine, 67 Asahi-machi, \\ Kurume-shi, Fukuoka 830 , and ${ }^{* * * *}$ Laboratory of \\ Veterinary Surgery, Faculty of Agriculture, \\ Kagoshima University, 1-21-24 \\ Korimoto, Kagoshima-shi, \\ Kagoshima 890, Japan
}

(Received 1 February 1994/Accepted 10 May 1994)

The influences of sex hormones on the dilatation of the urinary tubules and acidophil bodies were histologically investigated in NON (Non-Obese Non-diabetic) mice. Although the dilatation of the proximal tubules and acidophil bodies in NON mice were observed only in female but not in male, a slight dilatation and a few bodies were also observed in castrated male NON mice. Moreover, in ovariectomized female NON mice the dilatation and bodies were less compared with intact female NON mice. Estradiol administration induced prominent dilatation and numerous acidophil bodies, while the administration of testosterone showed a complete preventive effect. Therefore, it is suggested that the dilatation of the tubules and the acidophil bodies can be profoundly influenced by sex hormones. KEY WORDS : acidophil bodies, dilatation of the proximal tubules, NON mice, sex hormone

\author{
NON マウスにおける腎尿細管拡張および酸好性小体の \\ 出現に及ぼす性ホルモンの影響 \\ 佐畑ひとみ・鈴木秀 作*・吾 郷 昭夫** \\ 御船弘治***・坂本 紘**** \\ 財団法人島根難病研究所 \\ *鹿児島大学医学部附属動物実験施設 \\ **島根医科大学医学部附属動物実験施設 \\ ***久留米大学医学部動物実験センター \\ ****鹿児島大学農学部家畜外科学教室
}


Diabetic) マウスの亜型であり，顕性糖尿は発症しない が耐糖能異常を示すことから, II 型糖尿病のモデルと しての有用性が検討されている。著者らは，このNON 系統の雌マウスにおいてのみ, 堅蔵の近位尿細管に拡 張がおこり, 更に酸好性でPAS 陽性の小体が出現し, これらが加柃と共に顕著になることを指摘した。そし てこれらには性ホルモンが関与している可能性が考え られた。本報告では, 更にNON マウス雄の精巣摘除, 雌の卵巣摘除, それらに雌性ホルモンあるいは雄性ホ ルモンを投与することによって, 拡張と小体の出現に 性ホルモンが影響するか否かについて検討した。

実験には塩野義製薬研究所由来で, 島根医科大学附 属動物実験施設にて飼育繁殖を行った NON マウスの 雌雄計 280 匹を使用した。飼育温度は $23 \pm 3{ }^{\circ} \mathrm{C}$, 湿度 $50 \pm 10 \%$, 照明は 12 時間 $(8 \sim 20$ 時) で, 飼料は高圧 蒸気減菌した固形飼料（日本クレア CE-2）, 飲水は水 道水を自由に捸らせた。飼育は 1 ケージ $(175 \times 45 \times 125$ $\mathrm{mm} ）$ に 匹収容して行った。実験は雄マウス群とし て, 無処置群, 精巣摘除群, 無処置及び精巣摘除に加 えて Estradiol benzoateを投与した群（以下 Eb 群）, Testosterone propionate を投与した群(以下 Tp 群)の 6 群を設定し, 各群それぞれ 5〜10匹とした。なお, 精巣摘除は30日㔂時に, ペントバルビタール麻醉下で 腹部正中切開により行った。雌マウス群として, 無処 置群, 卵巣摘除群, 無処置及び贸巣摘除 $\mathrm{Tp}$ 群として それぞれ10匹を配した。卵巣摘除は30日粭時にペント バルビタール麻酔下で背部切開により行った。性ホル モン投与の為に, 雄性ホルモン Estradiol ( $\beta$-estradiol 3-benzoate: 和光純薬, Lot No. TLM7876) は0.02 $\mathrm{mg} / 0.1 \mathrm{~m} \ell$ の割に, また雄性ホルモン Testosterone (testosterone propionate: 和光純薬, Lot No. KPL 1689)は $1 \mathrm{mg} / 0.1 \mathrm{~m} \ell$ の割にごま油に溶解した。投与 は, それぞれ30日秢から120日秢および150日粭まで週 1 回䅡部皮下に投与した。マウスは60，90，120および 150日秢でペントバルビタール（ソムノペンチール）麻 酔後に放血屠殺した。堅䃘をブアン固定後， $6 \mu \mathrm{m}$ の パラフィン切片とし, hematoxylin-eosin (HE), Masson tricrome (MT) 染色, periodic-acid-Schiff (PAS) 反応を行い観察した。

\section{無処置群}

雄マウスでは60，90，120，150日齢のいずれにも尿 細管の拡張と小体は認められなかった。雌マウスでは, 60日秢以降，弱い拡張が出現しはじめ，90，120日柃と 加粭と共に明暸となった (Fig. 1.)。拡張した尿細管
の管腔内および細胞質内には，エオジン好性でPASに 強く反応し, MT 染色で青色に染まる大小不同の酸好 性の小体が多数観察された（Fig. 2.)。150日秢になる と拡張は更に著しく, 小体も增加した。拡張した尿細 管の細胞表面には PAS 陽性の刷子縁が明瞭に認められ ることから，本部位は近位尿細管と考えられる。

精巣および贸巣摘除群

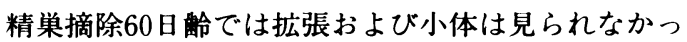
たが，90日秢では一部の近位尿細管に弱い拡張と小数 の小体が観察され始めた。120日粭では近位尿細管全体 に精巣摘除90日㱓のものとほほ同程度の拡張が観察さ れ，小体は一部の尿細管の細胞質および管胿内に見ら れた。150日秢では拡張の程度は, 精巣摘除90，120日 秢のものとほほ同様であったが, 小体は尿細管全体に 顕著に観察された（Fig. 3.)。

卵巣摘除群 $60 ， 90 ， 120$ 日䑪及び 150 日齢では拡張と 小体は無処置群のそれに比べかなり減少した。特に, 拡張についてはその差は明らかであった（Fig. 4.)。 エストラジオール投与群

無処置雄 $\mathrm{Eb}$ 群 150 日粭の腎䃘では，拡張は精巣摘除 群の同日秢のものとほほ同程度かそれよりやや強い程 度で，小体もほとんど同程度の出現であった。精巣摘 除 $\mathrm{Eb}$ 群150日粭では, 精巣摘除群の同日粭のものより もやや強い拡張と同程度の小体が観察された（Fig． 5.)。

\section{テストステロン投与群}

精巣摘除 Tp 群では，60，90，120日柃および150日 粭のいずれにおいても拡張と小体は全く観察されなか つた。無処置雄 $\mathrm{T} p$ 群も同様で变化はなかった。無処置 雌 $\mathrm{Tp}$ 群と卵巣摘除 $\mathrm{Tp}$ 群においても, 無処置の雌で観 察された顕著な搪張と小体はいずれの日粭においても 全く観察されなかった（Fig. 6.)。

\section{ごま油投与群}

ごま油を投与した群は投与しなかった群と比べて差 異は認められなかった。

NOD, NON マウス共に免疫不全の動物といわれ, あらゆる葴器にリンパ球を主とする細胞浸潤が現れる のが特徴とされる $[3,9]$ 。既に報告されているように， NON マウスは I 型糖尿病のモデルである NOD マウス の里系であり, 耐糖尿異常は示す（雄は示すが, 雌は 示さない）が顕性糖尿は発症しないとされており, II 型糖尿病のモデルとしての有用性が検討されている [9]。最近では糖尿病のモデルとしてだけでなく，系 球体類脂肪蓄積症のモデルとしての研究も進められて 
いる $[10]$ 。

NON 䧳のみに，堅尿細管の拡張と酸好性で PAS 陽 性の小体が出現することが波多野 [3]，Tanigawa

[9] らによって，報告されたが，一般に尿細管の拡張 についての報告は少ない。また，七トの急性尿細管壊 死の腎生検で尿細管の拡張像が報告されている [8] が，性ホルモンとの関連については明らかでない。 Kỏenig ら [4] は雌マウスにテストステロンを投与す ることにより，腎尿細管上皮に多くのライソゾームが 出現し, 開口分泌により尿細管腔中へ放出されること を認めている。このライソゾームの增加は, マウスの 近位尿細管細胞における雄性ホルモン作用の特幑であ ると報告している。更にKöenig ら［5］はマウスにテ ストステロンを投与し, 酸性フォスファターゼ, $\beta$-グ ルクロニターゼに反応する好塩基性のミエロイド小体 の蓄積を認め, これがエキトサイトーシスによって㔖 出，分泌されることを報告している。

一方，マウスにおけるエストラジオールの腎臓に及 ほす作用についての報告は見られないが, Hacker ら

［2］はシリアンハムスターの腎喊の近位尿細管にエス トロゲンで引き起こされる腫瘍を認め, Goldfarb ら

［1］もまた，去勢されたシリアンハムスターでエスト ロゲンが高率に腫瘍を引き起こすことを報告している。

また, Oberley ら [6] はシリアンハムスターにエス トロゲンを投与することにより近位尿細管に rate positive nucleus が出現することから，これはエストロゲン による特徴的なものであると報告している。

NON マウスに見られる酸好性で PAS 陽性の小体 は，テストステロン作用のミエロイド小体やエストロ ゲンで誘発される rate positive nucleus と類似してい るが，今回の観察ではこれらの関係を明らかに出来な かった。しかしながら，今回の NON マウスに見られ た小体と rate positive nucleus は, エストラジオール に強く影響されることから考えれば，同種のものであ る可能性も大きい。

NON マウスの堅䑏の尿細管拡張と小体の出現におけ るエストラジオールの生理学的な役割は明らかではな いが, 今回, 尿細管の拡張や小体がステロイドで促進 あるいは抑制されたことより，その発現機序について は興味の持たれるところである。

又, 系球体衰と近位尿細管の細胞がテストステロン
に過形成で応答する［7］など、腎蔵は性ホルモンの標 的器官の一つであると言われている様に, NON マウス が今後, 性ホルモンに関連する何らかのモデル動物に なりえる可能性も捨てきれない。その有用性について も更に検討しなければならない。又, 拡張と小体の出 現は，共に性ホルモンに強く影響されることから，両 者の因果関係についても更に検討していきたい。

\section{要約}

NON マウス（Non-Obese Non-diabetic）の雌にの み観察される腎㖑の近位尿細管の搪張と酸好性の小体 の出現に及ぼす性ホルモンの影響について組織学的に 検討した。雄マウスは精巣摘除により, 弱い拡張と少 数の小体が観察された。一方, 雌マウスでは卵巣摘除 により，それらの出現の程度が弱くなった。エストラ ジオール投与により, 正常雄にも拡張と小体が出現し た。テストステロンを投与された正常雌や精巣摘除雄 および卵巣摘除䧳には拡張と小体は認められなかった。 以上の結果は，NON マウスの腎䃘の尿細管の拡張と小 体の出現に, 雌性ホルモンが促進的に雄性ホルモンが 抑制的に作用することを示している。

\section{文献}

[1] Goldfarb, S. and Pugh, T. D., (1990). Cancer Research., 501, 113-119.

[2] Hacker, H. J., Vollmer, G., Chiquet-Ehrismann, R., Bannasch, P., and Liehr, J. G., (1991). Virchows Archiv B. Cell-Pathology, 60., 213-223.

［3］波多野弘美・鈴木秀作・谷川敬一郎・吾郷昭夫 (1988). 実 験動物, 37, 479-483.

[4] Köenig, H., Goldstone, A., and Hughes, C., (1978). Laboratory Investigation, 39, 4, 329.

[5] Köenig, H., Goldstone, A., Blume, G., and Chung, Y. L., (1980). Science, 209, 1023-1026.

[6] Oberley, T. D., Gonzalez, A., Lauchner, L. J., Oberley, L. W., and Li, J. J., (1991). Cancer Research, 51, 1922-1929.

[7] Rossier, B. C., Geering, K., Atkinson, J., and Roch-Ramel, F., (1985). Physiology and Pathophysiology, 1, 775-806.

［8］清水 章・益田幸成・杉崎祐一・山中宣昭（1991）。日本病 理学会会誌, 80, 113.

[9] Tanigawa, K., Suzuki, S., Sahata, H., and Kato, Y., (1992). Current Concepts Of A New Animal Model, pp. 123-129, Sakamoto, N. Hotta, N., and Utida, K. (eds.) .

[10）財甩法人 ヒューマンサイエンス振興財団. (1990)。疾患 モデル動物の維持。分与等に関するアンケート」調査報告 書. 


\section{Explanation of Figures}

Fig. 1. Light micrograph of the kidney in a female NON mouse (150-day-old). Note the striking dilatation of the urinary tubules (arrowheads). PAS. $4 \times 3.3$

Fig. 2. Light micrograph of the dilated proximal tubules in a female NON mouse (150-day-old). Acidophil bodies (arrows) are observed in the cytoplasm. PAS. $40 \times 3.3$

Fig. 3. Light micrograph of the proximal tubules in a castrated male NON mouse (150-day-old). The dilatation of the urinary tubules and the acidophil bodies (arrows) are observed. PAS. $40 \times 3.3$

Fig. 4. Light micrograph of the kidney in an ovariectomized female NON mouse (150-day-old). The dilatation of the urinary tubules (arrowheads) are not strong compared to that of an intact female NON mouse at 150 days old (see Fig. 1.). PAS. $4 \times 3.3$

Fig. 5. Light micrograph of the proximal tubules in a castrated male NON mouse treated with estradiol (150-day-old). The prominent dilatation of the urinary tubules and acidophil bodies (arrows) are notied. PAS. $40 \times 3.3$

Fig. 6. Light micrograph of the kidney in an ovariectomized female NON mouse treated with testosterone (150-day-old). The dilatation of the urinary tubules and the acidophil bodies are not ovserved. PAS. $4 \times 3.3$ 


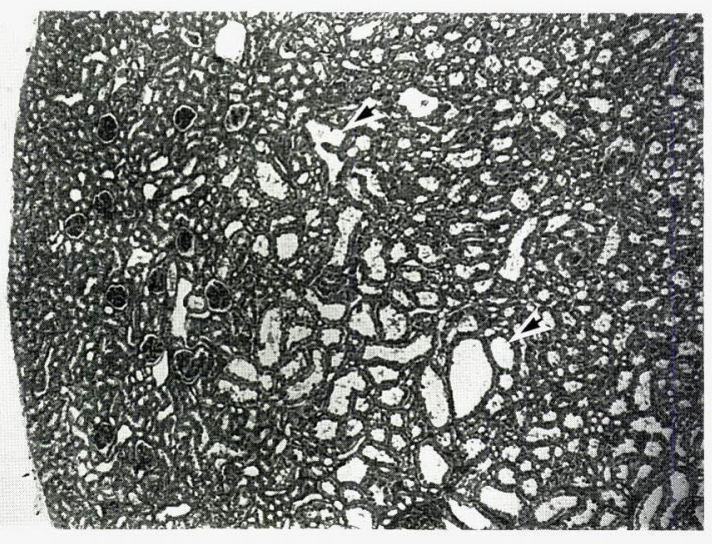

Fig. 1 .

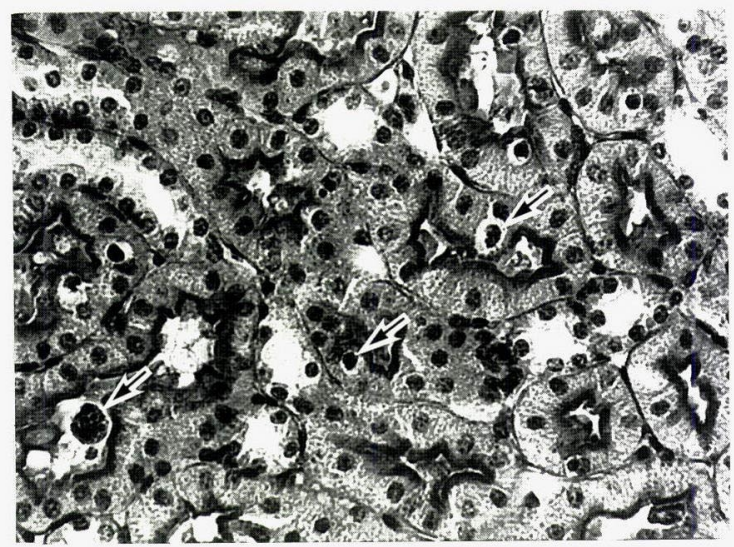

Fig. 3.

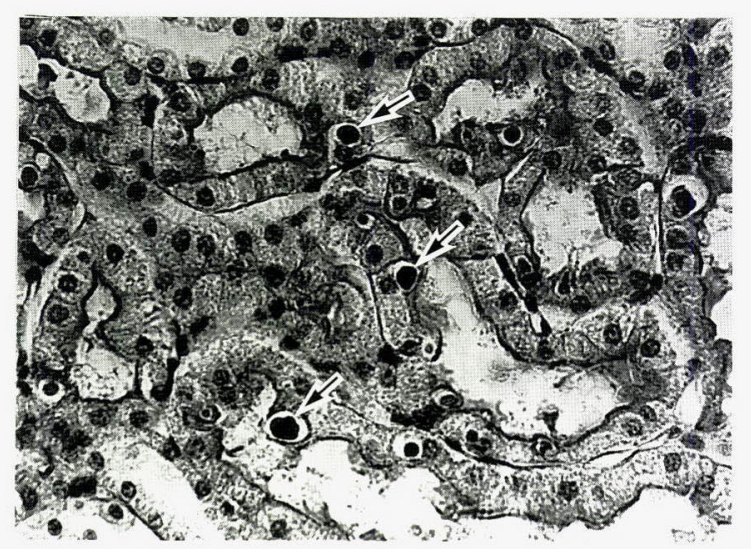

Fig. 5.

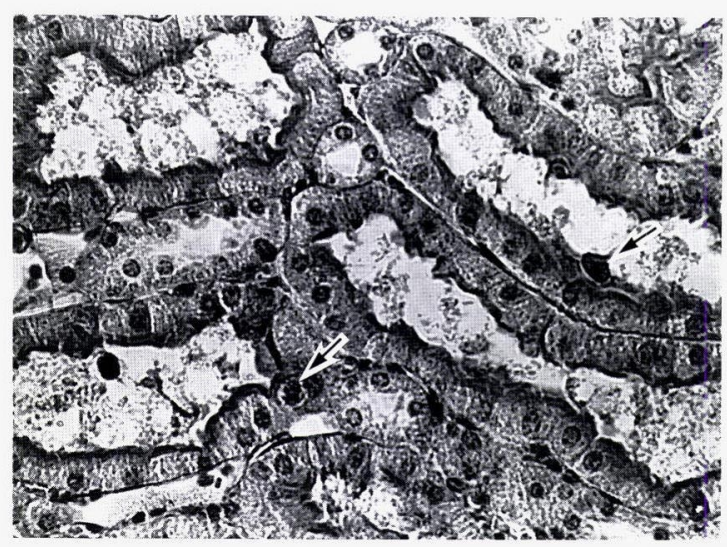

Fig. 2 .

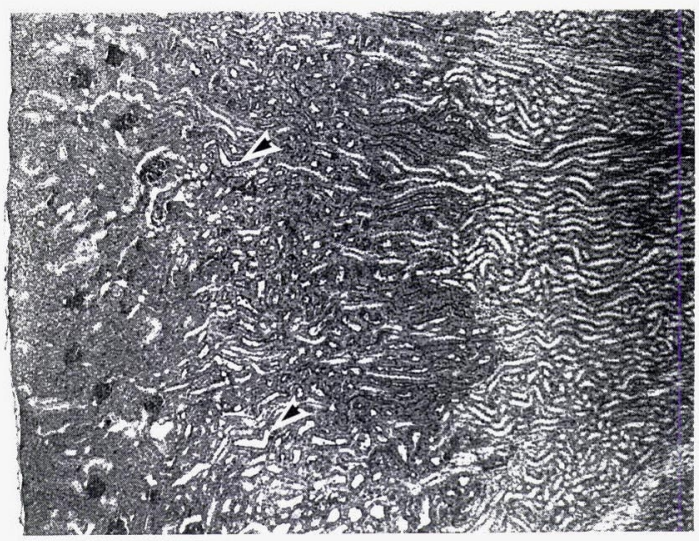

Fig. 4 .

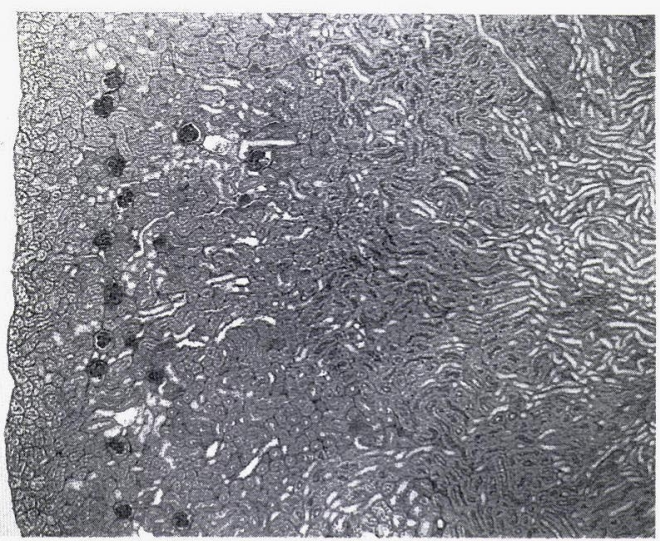

Fig. 6 